\title{
Hyper-intensive farming white shrimp Litopenaeus vannamei (Decapoda: Penaeidae) in a seawater tank under semi-controlled conditions
}

\author{
A.A. Ortega-Salas and L.A. Rendón M. \\ Unidad Académica Mazatlán, Instituto de Ciencias del Mar y Limnología, UNAM. Calzada Joel M. Camarena s/n, Mazatlán 82040, Sinaloa, México. \\ Apdo.Post.811, ortsal@ola.icmyl.unam.mx
}

Received 3-XII-2012 Corrected 15-I-2013 Accepted 30-I-2013

\section{ABSTRACT}

Shrimp development to a commercial size in high density culture saves food and avoids predators and disease. Our study was conducted to calculate the growth of white shrimp Litopenaeus vannamei by hyperintensive cultivation under semi-controlled conditions. We seeded at a density of 550 shrimp per $\mathrm{m}^{3}$ during the first cycle and 400 shrimp per $\mathrm{m}^{3}$ in the second cycle in an outdoor tank of $6 \mathrm{~m}^{3}$ or $6 \mathrm{~m}^{2}$ covered with mesh, constant aeration. The shrimp were fed Artemia franciscana during the first two weeks and camaronina pellets ( $35 \%$ protein) as required, in food baskets, aftterwards. The temperature ranged from 22,3 to $31,3^{\circ} \mathrm{C}$, $\mathrm{pH} 7,5-8,7$, oxygen $4,26 \pm 1,43$. The tanks are siphoned of debris every other day, and water was replaced according to a program. The food conversion ratio (FCR) was $1: 1,3$. The shrimp were measured weekly to calculate growth with the Bertalanffy model. Survival in the first cycle was 95,8 ( $97,9 \%$ for the second cycle). Population parameters (maximum likelihood method) for the first cycle were $k=0,0301, L \infty=322,16$ and $t_{0}$ $=-0,8852$; second cycle: $\mathrm{k}=0,0203, \mathrm{~L} \infty=294,42$ and $\mathrm{t}_{0}=-5,3771$. There was rapid growth during the first 10 weeks. Biomass was $27 \mathrm{~kg}$ for the first cycle (second: $16 \mathrm{~kg}$ ).

\section{KEY WORDS}

Growth, high density, survival, biomass, semi-controlled conditions.

\section{RESUMEN}

Es importante que en un espacio reducido se puedan desarrollar camarones a una talla comercial con alta densidad, se ahorra alimento, se evitan depredadores y enfermedades. El estudio se realizó con el fin de calcular el crecimiento de camarón blanco Litopenaeus vannamei mediante un cultivo hiper-intensivo y en condiciones semi-controladas. Se sembraron a una densidad de 550 camarones por $\mathrm{m}^{3}$ durante el primer ciclo y de 400 camarones por $\mathrm{m}^{3}$ en el segundo ciclo en un estanque de $6 \mathrm{~m}^{3} \circ 6 \mathrm{~m}^{2}$ al aire libre, se mantuvo tapado con una malla, la aireación fue constante, se les alimentó con Artemia franciscana durante las dos primeras semanas y luego con pellets de camaronina con $35 \%$ de proteína, como lo demandaban, en canastas de alimentación. La temperatura varió entre 22,3 a $31,3^{\circ} \mathrm{C}$., el $\mathrm{pH}$ entre 7,5 y 8,7 , el oxígeno tuvo 4,26 $\pm 1,43$; los estanques se sifonearon de detritus cada tercer día, y se hicieron recambios del volumen de agua de acuerdo a un programa. La proporción de conversión alimenticia (FCR) fue de 1:1.3. Los camarones se midieron en longitud y peso semanalmente para calcular el crecimiento, utilizando el modelo de Bertalanffy. La sobrevivencia en el primer ciclo fue 95,8 y $97,9 \%$ para el segundo ciclo. Los parámetros poblacionales por el método de máxima verosimilitud del primer ciclo fueron $\mathrm{k}=0,0301, \mathrm{~L} \infty=322,16$ y $\mathrm{t}_{0}=-0,8852$; en el segundo ciclo $\mathrm{k}=0,0203$, $L \infty=294,42 y t_{0}=-5,3771$. Los resultados indican un crecimiento acelerado durante las primeras 10 semanas. Se obtuvo una biomasa de $27 \mathrm{~kg}$ para el primer ciclo y $16 \mathrm{~kg}$ para el segundo ciclo.

PALABRAS CLAVE

Crecimiento, densidad alta, sobrevivencia, biomasa, condiciones semicontroladas. 
The expansion of shrimp farming industry has developed from extensive to intensive methods, dominating the production of semi-intensive system in the Northwest of Mexico with high quality food, laboratory postlarvae seeded and management techniques to date and disease prevention practices. The shrimp industry is currently operating more than $45000 \mathrm{Ha}$ of crops, with an increase in new development and expansion of capacity by more than $1500 \mathrm{Ha}$. (Gutierrez-Venegas, 2006).

The DICTUS (Department of Scientific and Technological Research of the University of Sonora), since 1973 has developed a system known as hyper-intensive and Lumare (1988) it stands as a model where the density per hectare ranges between two and six millions of organisms, with a $300 \%$ daily water exchange, intensive feed, use of small tanks and with production reaching 10 to 112 tons per hectare, which is practiced in countries such as Japan and the United States (Hawaii).

Thailand has been improving their farming techniques, which has positioned them as countries with the highest rates of productivity (Limsuwan, 2005).

Wyban, Pruder, Leber \& Burzell (1989), reported densities for pre-fattening tanks of $1000 \mathrm{PL} / \mathrm{m}^{2}$, which according to Flores (1994), under these conditions the organisms reach 1 to $1,5 \mathrm{~g}$ in four to six weeks. In addition to mortality estimates for this stage is $30 \%$ and the final density juveniles $/ \mathrm{m}^{2}$ be 350 .

This study was performed to calculate the growth of white shrimp Litopenaeus vannamei by hyper-intensive cultivation under semi-controlled conditions.

\section{METHODOLOGY}

The work was conducted at the facilities of Mazatlan Academic Unit of the Institute of Marine Sciences and Limnology, UNAM (Northwest of Mexico). The planting of the first cycle began May 11 and ended on August 4, 2007 (summer). The planting of the second cycle began on 12 September to 5 December 2007 (autumn).

Sea water is drawn directly from the sea, is driven by means of a pump with a capacity of 5,0HP 3 400rpm through underground pipes connected to a system of silica sand filter, which go directly to a reservoir of $5000 \mathrm{~L}$ capacity. Hence, using 2"pipe supplies the tanks of the experimental area.

The air system has two electric blowers, one with capacity of 2,0Hp and another with capacity 1,0Hp. Aeration is supplied through PVC pipe 0,5inches in diameter. The measurement of ammonia $\left(\mathrm{NH}_{3}-\mathrm{N}\right)$ used a brand Ammonia Photometer HI 93715 HANNA model with measurement range of 0,00 to $9,99( \pm 0,05)$. The $\mathrm{pH}$ was measured with an error of 0,1 potentiometers Mark Hanna calibrated to buffer $\mathrm{pH}=7$ for oxygen measurement using the YSI 55 portable oximeter with a range of 0 to 20 (+$0,25)$, which allows salinity measurements with a precision of $0.1 \%$ and a range of 0 to $80 \%$. We used a mercury thermometer mark Broken, -20 to $110^{\circ} \mathrm{C}\left( \pm 1^{\circ} \mathrm{C}\right)$.

The culture of white shrimp L. vannamei was carried out in a tank $1,65 \times 3,66 \times 1,0 \mathrm{~m}$ deep $\left(6,03 \mathrm{~m}^{3}\right.$ or $\left.6,09 \mathrm{~m}^{2}\right)$. The culture is hyper-intensive, were sown at a rate of $550 \mathrm{PL} / \mathrm{m}^{3}$ in the first cycle and about 400PL/ $\mathrm{m}^{3}$ in the second cycle. It keeps the tank covered with a mosquito net. The postlarvae were acquired in laboratories located in "Aguaverde" Aqua Pacific, Rosario, Sinaloa. In his transfer we used plastic bags and coolers, which were given pure oxygen and live food, in this case Artemia. The postlarvae were received in two large tanks for acclimation, were acclimated to the tank water intended for seeded where they had a culture of Artemia, at a concentration of six Artemia per postlarvae and commercial food brand Joma 1000 F-4 foil and initiator according to Montealegre (2001). The change of water for acclimatization was fourth volume per day acclimation aquarium to complete the total volume of tank water gradually. The size of the postlarvae PL12 and PL14 ranged from the first cycle and between PL18 and PL20 for the second cycle.

For the cultivation of Artemia, first conducted a cultivation of microalgae (Chaetoceros muelleri Lemmerman) in order to provide the laboratories of Aqua Pacific provided food for the Artemia strain, another strain was also provided by the Laboratory of Genetics Center for Food and Development Research Unit Mazatlan. The culture media for microalgae were previously washed, filled with water at $35 \%$ salinity, disinfected with commercial sodium hypochlorite $6 \%(0,2 \mathrm{ml} / \mathrm{L})$ for twenty-four hours before being used, then neutralized with sodium thiosulfate (50ppm) and continuous aeration through plastic hoses. Before inoculating the microalgae in exponential phase of the production chain, the water was fertilized using the culture method F (Guillard, 1973).

The postlarvae were counted directly with the use of a mesh network of 300microns against-aphid; the network captured organisms were placed in a white dish for direct counting and then deposited in a bucket for transport to the tanks.

After the first week for the first cycle and the second week for the second cycle, they began to supply pet food in feeding trays as they demanded. Performance Food is supplied $35 \%$ LD brand NASSA protein, two servings in the morning and one in the afternoon, there will be checked every day to add or decrease the amount of food. 
Samples were taken seven days to make measurements of length and weight.

The length measurement is made with a millimeter ruler and Ohaus digital scale for weighing GT480. They also include dead organisms that may come out in the trays.

During the growing season is very important to siphoning the bottom of the tank with a hose diameter of 0,5inches, to avoid accumulation of detritus. A basket is placed in the output mosquito net to prevent some shrimp could escape down the drain at the time of siphoning.

We also carried out the water changes from the second week of initiation of the culture at a rate of $30 \%$ every seven days during the first three weeks of culture, then 40 $50 \%$ every five days for the next three weeks, from $50-60 \%$ every four days for the next three weeks and $60-90 \%$ in recent weeks every three to five days.

Once information is gathered statistical package used Excel Statistics and the statistical program version 6,0 (StatSoft Inc., Tulsa, OK). Was plotted and calculated the length-weight relationship and growth in length and weight over time (Figs. 1-3), using the equation of von Bertalanffy growth in weeks, $L_{(t)}=L_{\infty}\left(1-e^{-k(t-t)}\right)$ where $\mathrm{L}_{(\mathrm{t})}=$ total length prediction at time $\mathrm{t}, \mathrm{L} \infty=$ theoretically maximum length, $\mathrm{k}=$ instantaneous growth rate; $\mathrm{t}_{0}=$ theoretical time of onset of growth. We also performed the estimation of these population parameters by the method of maximum likelihood (L) (Hilborn \& Mangel, 1997), we applied the curve matching test using the $\mathrm{F}$ statistic with $3(\mathrm{~K}-1)$ and $(\mathrm{N}-3 . \mathrm{K})$ degrees of freedom, to make comparisons between the growth in length by weeks of two growing cycles.

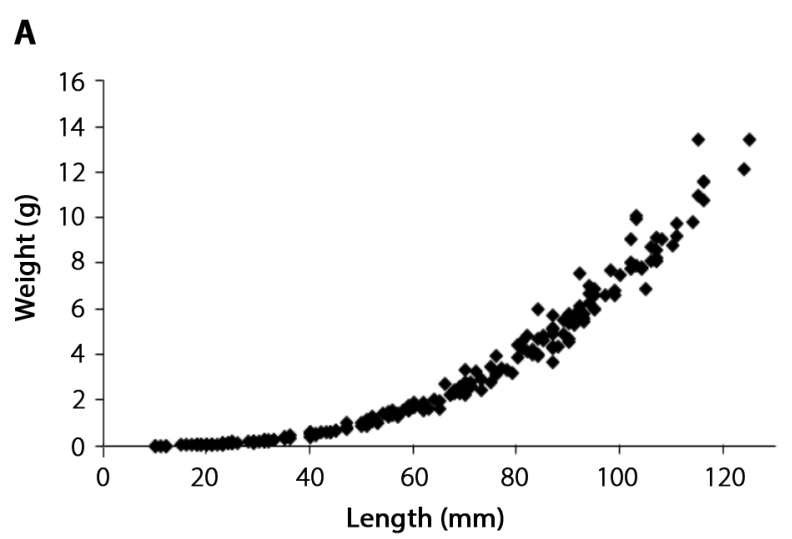

\section{RESULTS}

In the tank the temperature varied from 26,3 to $31,3^{\circ} \mathrm{C}$ in two cycles, the lowest was in the second season (autumn). The $\mathrm{pH}$ varied between 7,5 and 8,7 , the most important effect of $\mathrm{pH}$ on the tanks, is its effect on the ionization of ammonium, high values reduce the ionization of ammonium $\mathrm{NH}_{4}$ to $\mathrm{NH}_{3}$ (Hopkins et al., 1993). Dissolved oxygen is considered the water quality variable, more critical, the lowest measurement was 1,33 , towards the end of culture, but showed a mean of $4,26 \pm 1,43$. Salinity plays an important role in osmoregulation and ion transport SainzCarrion L. and Urias-Cuadras (2001), his average in both cycles was $30 \pm 4,27 \%$ o. Ammonium, variations in $\mathrm{N}^{-\mathrm{NH}_{3}}$ in the first cycle, a minimum concentration was 0,45 and the maximum is 1,24 , but had an average of $0,77 \pm 0,15$. In the second cycle the minimum concentration was 0.03 and the maximum was 2,86 , the average was $0,93 \pm 0,81$.

The weight-length relationship was performed and expressed in Figure 1, we applied a one-way ANOVA with significance of $95 \%$, to determine if there was an effect between the dependent variable in this case the weight and be independent length, gives a $F(1349,511)$ for the first cycle and F (2 299,373) for the second cycle, it was found that residues were normal, independent, zero mean and constant variance, obtaining for the first cycle, the following equation: $P=1 E-05 L 2,9393$, with an $R^{2}$ of 0,994 , and for the second cycle: $P=1 E-05$ L2,8697, with an $R^{2}$ of 0,993 . With the growth model of von Bertalanffy and tested with negative response surfaces of the natural logarithm of maximum likelihood, the growth parameters obtained for the first cycle: $L_{\infty}=322,16, K=0,0301$ and
B

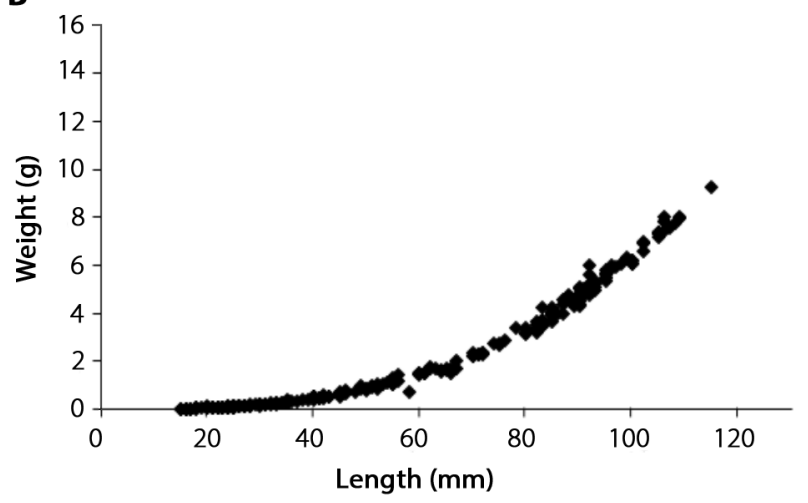

FIG. 1. (A) Weight-length relationship first cycle: $P=0,1014 L^{3,2747}, R^{2}=0,86$. (B) Weight-length relationship second cycle: $P=0,855$ $L^{2,693}, R^{2}=0,86$ 
$\mathrm{t}_{0}=-0,8852$, and for the second cycle: $\mathrm{L} \infty=322,16, \mathrm{~K}=0,0301$ and $\mathrm{t}_{0}=-0,8852$.

Growth is known as the increase in size and weight of individuals and is a function of culture time, influenced by population density, availability and quality of food and water quality parameters (Lara-Anguiano \& MaldonadoHernandez, 1995). Figure 2 with calculations shows further growth both in length and in weight in the first cycle, than in the second cycle. The average length of postlarvae used for the development of the first cycle was 7,5 $\pm 0,5$ $\mathrm{mm}$, while for the second cycle; the average length was $19,25 \mathrm{~mm}$. In the first cycle were sown 3400 organisms in $6,03 \mathrm{~m}^{3}$ or $6,09 \mathrm{~m}^{2}$, the number of organisms remain was 3100 , we obtained a survival rate of $91,2 \%$, the average weight per week was $0,0255 \mathrm{~g}$ to obtain the final average weight of $8,8295 \mathrm{~g}$, the percentage of weekly food was of $15,56 \%$ to $3,80 \%$, the food conversion ratio was the $1: 1$ to $1: 1,4$, total biomass was $27,3 \mathrm{~kg}$ harvested. In the second cycle were twelve weeks of culture were seeded
2400 organisms in $6 \mathrm{~m}^{2}$, the number of organisms remain were 2350 was obtained a survival rate of $97,9 \%$, the average weight per week was $0,0631 \mathrm{~g}$ of until a final average weight of $7,03 \mathrm{~g}$, the percentage of weekly food was of $17,7 \%$ to $2,41 \%$, the food conversion ratio was of $1: 1,2$ to 1: 1,4 , total biomass was $16,5 \mathrm{~kg}$ harvested.

We applied the maximum likelihood method to find the parameters of von Bertalanffy growth, this method is more efficient because it minimizes the response surface in search of values. Some Bertalanffy growth parameters described by authors are as follows (Table 1).

\section{DISCUSSION}

Boyd (1989) considers that the species commonly cultivated in tanks grow best in the range of 23 to $3^{\circ} \mathrm{C}$. Other authors such as Bassanesi-Poli (1987), Ruiz-Fernandez (1995), indicate temperatures in semi-extensive
A

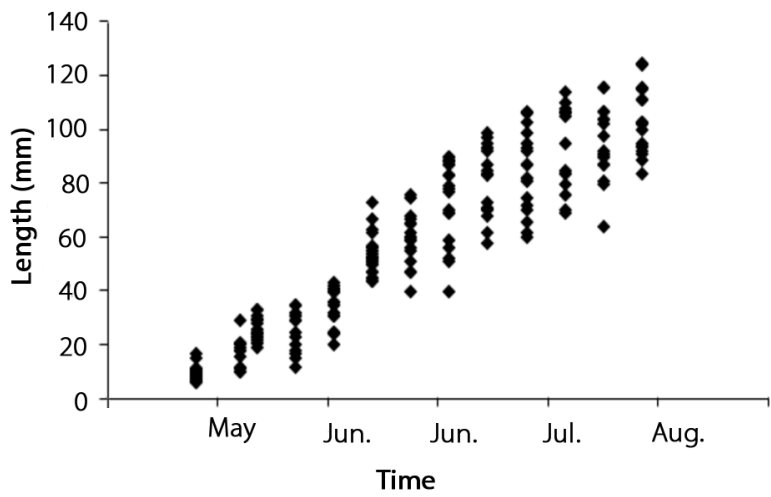

C

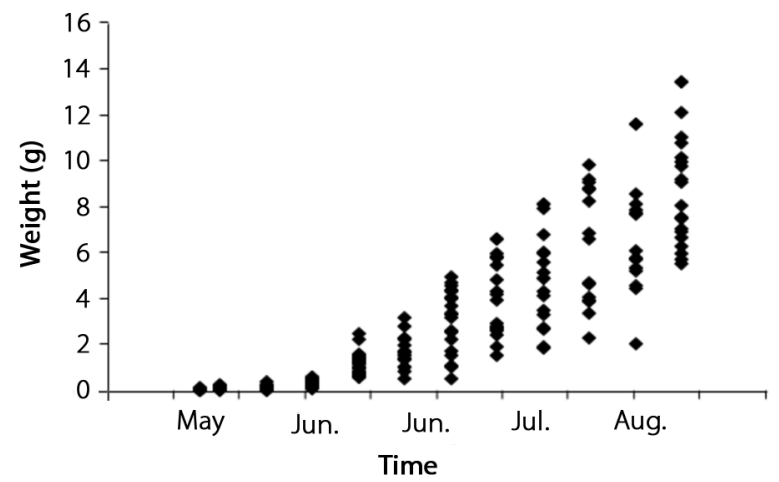

B

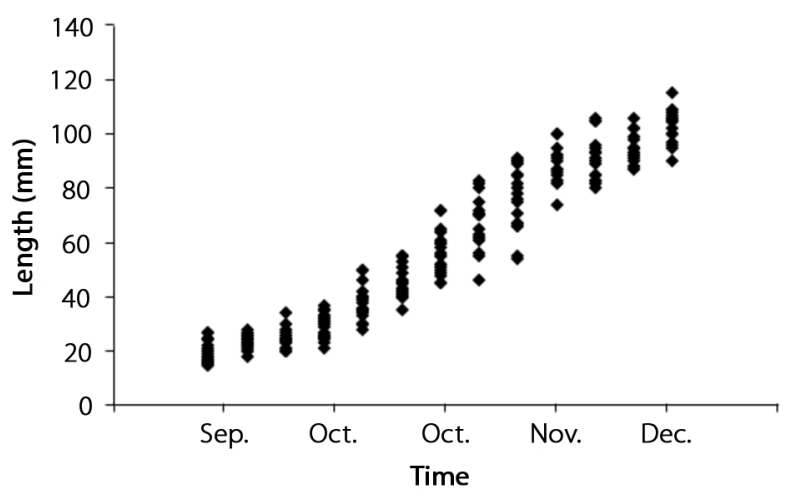

D

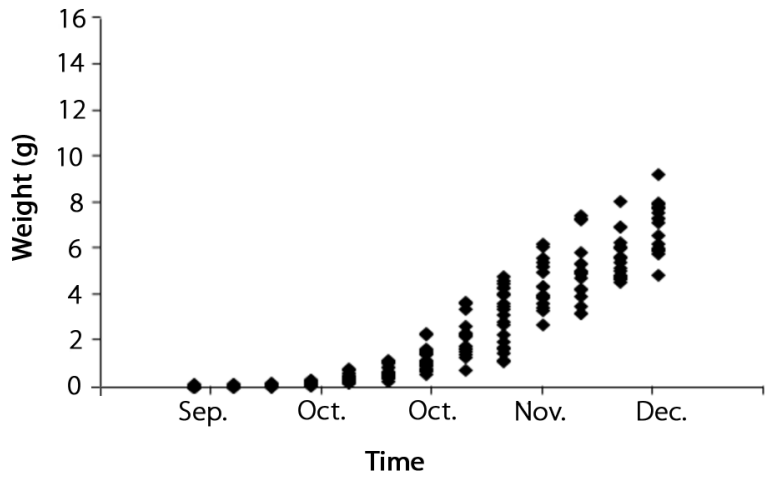

FIG. 2. (A) Growth in the first cycle length: $L \infty=322,16, K=0,0301, t_{0}=-0,8852$. (B) Growth in the second cycle length: $L \infty=294,42$, $K=0,0203, t_{0}=-5,3771$. (C) Growth in weight the first cycle: $P(t)=0,1014, L(t) 3,2747, R 2=0,86$. (D) Growth in weight second cycle: $P(t)=0,0855, L(t) 2,693, R^{2}=0,86$ 


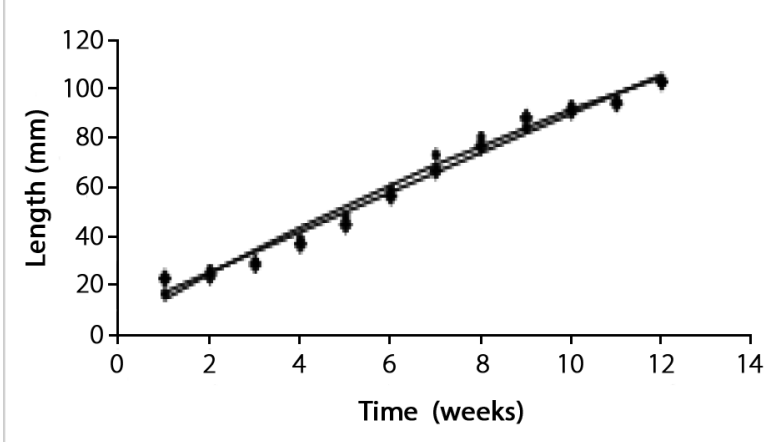

FIG. 3. Growth curves of von Bertalanffy test applying the matching curves for the growth of organisms in the first cycle against the second cycle, the points represent the first cycle and the diamonds the second cycle.
TABLE 1

Some parameters of growth in shrimp reported by other authors.

\begin{tabular}{cccc}
\hline Author & $\mathrm{L} \infty$ & $\mathrm{K}$ & t0 \\
\hline $\begin{array}{c}\text { Bush Medina } \\
(2004)\end{array}$ & 223,8 & $1,95-2,2$ & \\
$\begin{array}{c}\text { Castro et al., } \\
\text { (1987) }\end{array}$ & $\begin{array}{c}199,1 \\
\text { - }\end{array}$ & $0,12-0,15$ & $-1,235,-1,26$ \\
Castro and & & $0,22-0,21$ & \\
Sánchez (1976) & & $-0,28$ & \\
Galicia (1976) & & 0,21 & \\
Nuñez (1988) & & 0,21 & \\
Shultz and & $223-210$ & $0,183-0,226$ & $-0,254$, \\
Chavez (1976) & -216 & -0207 & $-0,327$, \\
& & &
\end{tabular}

rustic tanks similar to those mentioned above. Garza-Bravo (1998) concludes that the best growth of $L$. vannamei is given in a combination of temperature of $30^{\circ} \mathrm{C}$ and a salinity of $15 \%$. In this work the temperatures recorded during the first cycle coincide with those of the authors, mainly due to the entrance of the rainy season in the region represents an increase in room temperature, otherwise it goes in the cultivation of the second cycle as they have decreases in temperatures of up to $8^{\circ} \mathrm{C}$ with temperatures reaching up to $22^{\circ} \mathrm{C}$, this for the entrance of the dry season in the region, and therefore attributed a smaller increase in length and weight than those recorded in the first cycle. The two growth factors that are molting frequency and molt size increment (Hartnoll, 1982), and the temperature is the factor that most affects the duration of the molt cycle, when it increases, the cycle becomes shorter. Further growth both in length and in weight in the first cycle, than in the second cycle, probably because the temperature was more high (summer), the second cycle was developed in autumn with lower temperatures and less postlarvae were sown.

Tsai (1990) considers that lower levels of $\mathrm{pH}$ to 4,8 and greater than 10,6 are lethal to penaeids, in the present study, the $\mathrm{pH}$ ranged between 7,5 and 8,7 is considered acceptable.

Oxygen is the most limiting variable, Boyd and Fast (1992) recommend that the best growth of penaeids is obtained dissolved oxygen concentrations between 3,5 saturation values of less than 1 can be lethal in this paper, the measurement was 1,33 lower, towards the end of culture, but showed a mean of $4,26 \pm 1,43$. According to Boyd (1989), ammonium toxicity is expressed rather by reduced rates of growth rather than death in this study; there were higher values in the second cycle.

Zarain-Herzberg (2007), reports floating cage densities in Sinaloa of 700 organisms per $\mathrm{m}^{2}$ for a phase of pre-breeding or pre-fattening, later moving to a density of 200 organisms $/ \mathrm{m}^{2}$. In this work we opted for two seeding densities without pre-breeding phase or pre-fattening only had a period of acclimation, which was 550 organis$\mathrm{mos} / \mathrm{m}^{3}$ for the first cycle and 400 organismos $/ \mathrm{m}^{3}$ for the second cycle. In Thailand, have yields of $15 \mathrm{ton} / \mathrm{Ha}$, in this work, if one could extrapolate per hectare in both seasons ranged from 29,4 to 45,6 ton/Ha. In a farm intensive cultivation of shrimp in Nayarit with stocking densities of 80 postlarvas $/ \mathrm{m}^{2}$ survival were obtained with yields of $80,55 \%$ 18,04tons/Ha (Olguin-Pineda, 2006).

\section{ACKNOWLEDGEMENTS}

We thank the technical support of A. Nuñez P., S. Rendón R. and M.H. Castro.

\section{REFERENCES}

Bassanesi-Poli, A.T. (1987). Análisis de un cultivo de camarón blanco (Penaeus vannamei, Boone) en estanques rústicos en San Blas, Nayarit, México. Tesis doctoral, UACP y P-CCH, UNAM, México.

Boyd, C.E. (1989). Water quality management and aeration in shrimp farming. Fisheries and Allied Aquacultures 
Departmental Series No. 2, Alabama Agricultural Experiment Station, Auburn University, Alabama, USA.

Boyd, C. \& Fast, AW. (1992). Pond monitoring and management. In Marine shrimp culture: principles and practices. Developments in aquaculture and fisheries science, $v 23$. The Netherlands: Els. Sc. Pub. B.V.

Bush Medina, R.E. (2004). Crecimiento del camarón azul (Litopenaeus stylirostrisStimpson, 1984) en el sistema lagunar de navachiste Sinaloa, México. Tesis de Licenciatura. Facultad de Ciencias del Mar. Universidad Autónoma de Sinaloa, México.

Flores, N.A. (1994). Desarrollo científico y tecnológico del cultivo de camarón blanco del golfo Penaeussetiferus en estanques circulares. Convenio SEPESCA-CINVESTAV Mérida, México.

Galicia, H.R. (1976).Crecimiento de camarón azúl (Penaeus stylirostris) y camarón café ( $P$. californiensis) en la zona de Puerto Peñasco, Sonora. Mem. Simp. Biol. Din. Pobl. I.N.P. 2:447-518.

Garza-Bravo, F.J. (1998). Efectos de la temperatura y salinidad sobre el crecimiento consume de alimento y sobrevivencia de postlarvas de Litopenaues vannamei (Boone, 1931). Tesis de licenciatura. FACIMAR. UAS. Mazatlán, México.

Guillard, R.R.L. (1973). Methods for microflagellates and nannoplakton. In J. R. Stein (Ed.) Handbook of phycological methods-culture methods and growth measurements. New York, USA: Cambridge Univ. Press.

Gutierrez-Venegas, J.L. (2006). Reporte Técnico-Económico del Cultivo de Camarón en México. In Industria Acuícola. Febrero-Marzo, 2(3),10-13.

Hartnoll, R.C. (1982). Growth. In Abele, L. G. (Ed.) The biology of Crustacea, Vol. 2, Embryology, morphology, and genetics. New York, USA: Academic Press.

Hilborn, R.R. \& Mangel, M. (1997). The ecological detective. Confrontating models with data. New York, USA: Princeton University Press.

Hopkins, J., Stephen, R.D., Hamilton, P.A. Sandifer, C.L., Browdy \& Stokes, A.D. (1993). Effect of water exchange rate on production, water quality, effluent characteristics and nitrogen budgets of intensive shrimp ponds. Jour. World Aquac. Soc. 24(3).

Lara-Anguiano, G.F. \& Maldonado-Hernandez W. (1995). Influencia de los factores bióticos y abioticos en el crecimiento del camarón blanco Litopenaeus vannamei y su recuperación en los costos de producción en la granja SCPP "Clementina" SC. Tesis de licenciatura. FACIMAR. UAS. Mazatlán, México.
Limsuwan, C. (2005). Cultivo intensivo del camarón blanco. (Resumen de visitas y conferencias a camaroneras del Perú en Noviembre 2005). In Dagoberto S., T. (Ed.) Octubre Diciembre 2005.

Lumare, F. (1988). Penaeus japonicus: Biologia e allevamento. In Alexandra, G. (Ed) Penaeus japonicus: Biologia e Spermentazione. E.S.A.V. entre Suilupo AgricoloVeneto, Italy.

Montealegre, J. (2001). Protocolo de larvicultura para Litopenaeus vannamei. Taller "Cultivo de camarones para inversionistas. Experiencia venezolana: 8Tm/ha". Maracaibo, Venezuela, 8-9 Junio de 2001.

Nuñez P.A. (1988). Crecimiento del camarón P. vannamei, P. stylirostris, P. californiensis y su relación con factores ambientales (temperatura y salinidad) en las lagunas Huizache-Caimanero, Sinaloa, México. Tesis de Maestría. UNAM, México.

Olguín-Pineda, M. (2006). Entrevista. In Reyes, F.M. (Ed.) Industria Acuícola. Mayo. 2(4), 16-19.

Pérez Vivar, T.L. (2003). Dinámica poblacional del camarón blanco Litopenaeus vannamei (Boone, 1931) en la plataforma continental de Sinaloa y Nayarit. Tesis de Maestría. ICMyLUNAM. Mazatlán, Sinaloa, México.

Ruíz-Fernandez, A.C. (1995).Calidad de agua de cuatro granjas camaronícolas en el noroeste de México: Estudio comparativo de las características físicas, químicas y de contribución orgánica de aguas de ingreso y egreso. Tesis de Maestría. ICMyL-UNAM. Mazatlán, México.

Sainz-Carrion, L. \& Urias-Cuadras, J.A. (2001). Determinación de las variables fisicoquímicas relacionadas con el crecimiento de Litopenaeus vannamei en un ciclo de cultivo semi-intensivo. Tesis de licenciatura. Biólogo acuicultor. FACIMAR. UAS. Mazatlán, México.

Tsai, C.K. (1990). Water quality management 56-63, In Akiyama, D.M. (Ed), Proc. Southeast Asia Shrimp Farm Management Workshop, Philippines, Indonesia, Thailand, 26 July-11 August 1989 American Soybean Association, Singapore.

Wyban, J.A., Pruder, G.D., Leber, K.M. \& Burzell, L. (1989). Efecto de la rueda de paletas sobre el crecimiento de camarón, la producción y el valor de la cosecha en estanques comerciales de tierra. J. Worl. Aquac Soc. 20(1), 18-23.

Zarain-Herzberg, M. (2007). Jaulas flotantes: una alternativa de cultivo. Industria Acuícola, 2, 17-19. 